\title{
Configurações
}

configurações

Revista de sociologia

$9 \mid 2012$

Trabalho e género: vidas precárias, percursos e acção colectiva

\section{Nota prévia}

\section{Manuel Carlos Silva}

\section{(2) OpenEdition \\ 1 Journals}

\section{Edição electrónica}

URL: http://journals.openedition.org/configuracoes/1221

DOI: 10.4000/configuracoes. 1221

ISSN: 2182-7419

\section{Editora}

Centro de Investigação em Ciências Sociais

\section{Edição impressa}

Data de publição: 30 junho 2012

ISSN: 1646-5075

\section{Refêrencia eletrónica}

Manuel Carlos Silva, « Nota prévia », Configurações [Online], 9 | 2012, posto online no dia 18 dezembro 2013, consultado o 22 setembro 2020. URL : http://journals.openedition.org/configuracoes/1221 ;

DOI : https://doi.org/10.4000/configuracoes. 1221

Este documento foi criado de forma automática no dia 22 setembro 2020.

(c) CICS 


\title{
Nota prévia
}

\author{
Manuel Carlos Silva
}

1 Sem ser tematicamente fechado, este número 9 da Revista Configurações oferece aos leitores um conjunto de textos sobre temas que se relacionam directa ou indirectamente em torno de tópicos nucleares nas ciências sociais num registo de problematização teórica, sem deixar de anotar, nalguns deles, a apresentação de resultados empíricos: o trabalho e os processos de profissionalização no campo da formação sociológica; a importância das redes nas reconfigurações organizacionais recorrendo ao conceito de configuração no quadro do legado de Norbert Elias; a reconstituição etnográfica de vidas operárias; o fenómeno da precariedade atingindo particularmente a juventude e a articulação deste problema com o sindicalismo e a necessária acção colectiva; a delinquência juvenil feminina; a desigual divisão sexual do trabalho no espaço doméstico em detrimento da mulher; a perspectiva crítica feminista na análise da obra de Ana Bê; a análise, na esfera reprodutiva, dos processos de realojamento no pós-25 de Abril de 1974; o papel dos blogues nos processos de identifi cação e pertença em contexto empresarial; e, por fi $m$, a apresentação de uma recensão de uma obra sobre justiça, ambientes mediáticos e ordem social.

2 Enquanto Director do Centro de Investigação em Ciências Sociais (CICS), cabe-me manifestar aos autores dos artigos o apreço e o agradecimento pelo envio dos seus trabalhos para a Revista Confi gurações que, uma vez sujeitos à arbitragem científica e aprovados, valorizam certamente a própria revista com os seus contributos.

3 Por fim, às colegas Alice Delerue Matos e Ana Paula Marques que comigo partilharam a tarefa de leitura e organização dos textos antes e após a recepção dos referees uma especial palavra de reconhecimento, assim como à Ângela Matos, Secretária do CICS. 


\section{AUTOR}

MANUEL CARLOS SILVA

Diretor do CICS 